\title{
12: $107325559-107187814$
}

National Cancer Institute

\section{Source}

National Cancer Institute. 12: 107325559-107187814. NCI Thesaurus. Code C41974.

Physical location of CMKLR1_Gene 